\title{
Effect of integrated nutrient management on soil fertility and yield of maize crop (Zea mays) in Entic Haplustart in Tamil Nadu, India
}

\author{
V. Sanjivkumar \\ (Tamil Nadu), INDIA \\ E-mail: sanjivkumarv@rediffmail.com \\ Received: April 9, 2014; Revised received: May 25, 2014; Accepted: June 12, 2014
}

Department of Soil Science and Agricultural Chemistry, Tamil Nadu Agricultural University, Coimbatore-641003

\begin{abstract}
A field experiment was conducted to study the integrated use of organic and inorganic fertilizers on the soil fertility status of Entic Haplustart in maize at Malayalathanpatti village, situated at Madurai district during Kharif season of 2008-2009. The experiment was conducted in Randomized Block Design with three replications in Annaiyur soil series (Entic Haplustert). The results revealed that highest grain yield of $4402 \mathrm{~kg} \mathrm{ha}^{-1}$ was recorded in treatment that received vermicompost @ $5 \mathrm{t} \mathrm{ha}^{-1}$ with 75 percent Recommended dose of fertilizer (RDF) and it was found to be superior to over treatments. Application of vermicompost @ 5t ha ${ }^{-1}+75$ percent RDF recorded the highest calcium and magnesium content in pot harvest soil sample $(0.139$ and $0.281 \%)$. And also increased the crude protein $(16.67 \%)$ and starch $(81.34 \%)$ content in maize crop and it was followed by the treatment which received sewage sludge $2 \mathrm{t}$ ha $^{-1}$ with 75 percent RDF (Recommended dose of fertilizers) and green leaf manure @12.5t ha ${ }^{-1}$ whereas the lowest value was recorded in control plot respectively. The vermicompost along with inorganic fertilizers were efficiently used by maize crop for their growth and development and also maintainined soil fertility and increased yield of the crop.
\end{abstract}

Keywords: Maize crop, Organic and inorganic sources, Quality, RDF, Secondary nutrients

\section{INTRODUCTION}

The conjunctive application of organics with inorganic sources of nutrients reduces the dependence on chemical inputs (Vanlanwe et al., 2002). Utilization of indigenous sources of organics serve as alternatives and or supplements to chemical fertilizers and help in increasing the productivity of the maize (Seshaiah, 2000). Maize is globally the top ranking cereal in potential grain productivity. It is cultivated in tropical regions of the world. In India, maize is cultivated in about 7.59 million hectares with a production of 14.71 million tones. It is a very difficult task for our agriculturists to increase the maize production from the present level of 34 to 100 million tonnes. In Tamil Nadu maize is cultivated in an area of 0.20 million hectares with a production of 0.24 million tonnes and an average productivity of $1189 \mathrm{~kg} \mathrm{ha}^{-1}$ (Ministry of Agriculture, Crop Report, 2007). By 2020 AD, the requirement of maize for various sectors will be around 100 million tonnes, of which the poultry sector demand alone will be 31 million tonnes. It is a very difficult task for our agriculturists to increase the maize production from the present level of 34 to 100 million tonnes (Seshaiah, 2000). As the mineral fertilizer alone cannot meet the requirements of crops and cropping systems because of high cost and also environment related risks involved in its application and usage, integrated use of organics and inorganics is desired to attained the sustainability of a system. Integrated use of concentrated manure and chemical fertilizers improved the enzymatic activities as well as microbial population of bacteria, fungal and actinomycetes. Decomposition of organic matter and recycling of carbon have substatial effect on the activity of enzyme evolved in mineralization of nutrients. soil enzymes significantly contribute to soil health. Vermicomposting is one such viable technique for augmentation of organic source in soil. Application of vermicompost influences the physical, chemical and biological properties of soil. It improves the water holding capacity of the soil. Use of vermicomposting is being advocated for sustaining soil fertility in various field crops (Senthil Kumar and Surendran, 2002). The disposal of such sludges on agricultural lands offers potential for generation and recycling of nutrients. Sewage sludge apart from providing organic matter (contains around 50\% dry matter), may also enrich soils with other nutrients like nitrogen (1$7 \% \mathrm{~N})$, phosphorous $\left(1-5 \% \mathrm{P}_{2} \mathrm{O}_{5}\right)$, potassium $(0.1-3 \%$ $\mathrm{K}_{2} \mathrm{O}$ ) and other elements (Dowdy et al., 1978). Coir pith a by product of coir industry is available to the tune of 7.5 million tones per year in India. The raw coir pith can be composted with fungi (Pleurotus sajor caju, Trichoderma $s p$ and Aspergillus $s p$ ) and it can be concluded an idea manure with higher content of macro and micro nutrients. 
But at present, scarcity and unavailability of organic sources plant nutrients may be supplies through organic and inorganic sources for sustaining the productivity of crops. Keeping above in view the present investigation was conducted to study the effect of integrated nutrient management on soil fertility and yield of maize crop (Zea mays) in Entic Haplustart in Tamil Nadu.

\section{MATERIALS AND METHODS}

The experiment was conducted in farmer field the Malayalathanpatty village, situated at Madurai district during Kharif season of 2008-2009.

Treatment details: There were 10 treatments which includes $\mathrm{T}_{1}$-Control, $\mathrm{T}_{2}$-recommended dose of fertilizer (RDF), $\mathrm{T}_{3}-75 \% \mathrm{RDF}+25 \%$ vermicompost @ 5t ha ${ }^{-1}, \mathrm{~T}_{4}-100 \%$ vermicompost @ 5t ha ${ }^{-1}, \mathrm{~T}_{5}-75 \%$ $\mathrm{RDF}+25 \%$ green leaf manure @ 12.5t ha ${ }^{-1}, \mathrm{~T}_{6}-100 \%$ green leaf manure @ 12.5t ha ${ }^{-1}, \mathrm{~T}_{7}-75 \% \mathrm{RDF}+25 \%$ composted coir pith@10t ha ${ }^{-1}, \mathrm{~T}_{8}-100 \%$ composted coir pith@10t ha ${ }^{-1}, \mathrm{~T}_{9}-75 \% \mathrm{RDF}+25 \%$ sewage sludge @ 2t ha ${ }^{-1}, \mathrm{~T}_{10}-100 \%$ sewage sludge @ 2t ha ${ }^{-1}$ which were replicated thrice in a randomized block design. The test crop was maize (var. Super 900M). The experimental soil was of sandy clay loam (Clay$28.2 \%$, Silt-23.3\%, Fine sand-32.5\% and Coarse sand$13.8 \%$ ) texture and belong to Anaiyur soil series (Entic Haplustert). The soil was non-saline with alkaline reaction ( $\mathrm{pH} 8.2$ and EC $0.42 \mathrm{dS} \mathrm{m}^{-1}$ ) followed by method of Jackson (1973). The soil was low in alkaline $\mathrm{KMnO}_{4}-\mathrm{N}$, medium Olsen's $\mathrm{P}$ and high in $\mathrm{NH}_{4} \mathrm{OAc}-\mathrm{K}$ followed by method of Subbiah and Asija (1956), Olsen et al. (1954) and Stanford and English (1949). The crop was raised and grown up to 105 days and then harvested and then grain yield were recorded from the individual treatment wise and expressed in $\mathrm{kg} \mathrm{ha}^{-1}$. From the post harvest soil sample, soil were collected from each treatments and analysed for the available calcium and magnesium by Versanate method by Jackson (1973). Plant samples were collected from each treatment and analyzed for total $\mathrm{N}$ by Micro kjeldhal's method. The $\mathrm{N}$ content of the fruit was multiplied by the factor 6.25 to get the crude protein content of the fruit and expressed in percent method by Humphries (1956) and starch analysed by colorimetric method in maize crop.

Statistical analysis: The data obtained from the investigation were subjected to statistical scrutiny to determine the effects of treatments. The data were analyzed adopting randomized block design, and simple correlations were worked out to determine the possible relationships as described by Panse and Sukhatme (1967). The critical difference was worked out at 5 percent (0.05) probability.

\section{RESULTS AND DISCUSSION}

Physico-chemical properties of experimental soil: The initial soil sample collected from the experimental site before the commencement of experiment was

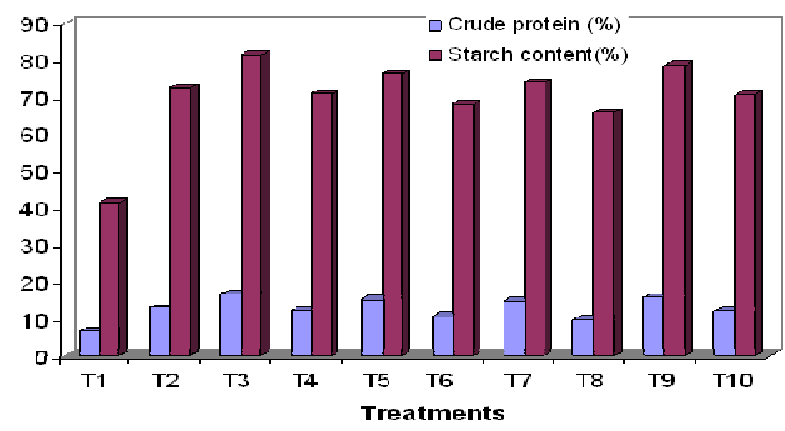

Fig.1. Effect of organic and in organic treatments on quality attributes of maize crop.

analyzed for the various physico-chemical properties. From the textural composition of soil, it was inferred that the soil was sandy loam. The cation exchange capacity of the soil was $14.8 \mathrm{C} \mathrm{mol}\left(\mathrm{P}^{+}\right) \mathrm{kg}^{-1}$. The $\mathrm{pH}$ was 8.2 with EC of $0.42 \mathrm{dSm}^{-1}$. The organic carbon content was 0.57 percent. The available nitrogen, phosphorus and potassium contents of the soil were $258.5,16.0$ and $265.3 \mathrm{~kg} \mathrm{ha}^{-1}$ respectively recording low, medium and medium status in soil fertility.

Yield: The yield of maize was significantly influenced by application of various sources of organic manures and it was ranged from 2096 to $4402 \mathrm{~kg} \mathrm{ha}^{-1}$. The result revealed that the plots which received the vermicompost @ 5t ha ${ }^{-1}$ with 75 percent RDF showed the highest yield attributes of $\left(4402 \mathrm{~kg} \mathrm{ha}^{-1}\right)$ of maize and it was followed by the application of $75 \% \mathrm{RDF}$ along with sewage sludge @ $2 \mathrm{t} \mathrm{ha}^{-1}$ then rest of the treatment tried (Table.1). The application of nutrients through inorganic sources also might have increased the yield of maize. In groundnut (JL-24), application of full dose of vermicompost or half the dose of vermicompost coupled with 25 to 50 percent of recommended dose of chemical fertilizers showed significant increase in yield over application of farm yard manure with recommended dose of chemical fertilizers, Kale and Bano (1992). Application of organic manures either alone or integrated with chemical amendments for maize, performed better than all amendments tested in laboratory trails studied by Mujeeb et al. (2010). Recommendation of organic matter alone with synthetic fertilizers could be helpful for enhancing stagnant wheat grain yield was repoted by Tahir et al. (2011). The lowest value was registered in the untreated check $\left(2096 \mathrm{~kg} \mathrm{ha}^{-1}\right)$.

Available calcium and magnesium: The available calcium was found superior when applied with organic and inorganic fertilizers and available calcium ranged from 0.110 to $0.139 \%$. The highest value of 0.139 percent was recorded in the treatment that received vermicompost @ 5t ha ${ }^{-1}$ with 75 percent RDF and it was followed by the application of sewage sludge @ $2 \mathrm{t}$ $\mathrm{ha}^{-1}+75$ percent RDF and green leaf manure @ 12.5t ha $^{-1}$ with 75 percent RDF with the value of 0.135 and 0.131 percent respectively. The least vale recorded in the control plot $0.110 \%$. The increase in the 
Table 1. Effect of organic and inorganic treatments on yield of maize crop.

\begin{tabular}{|c|c|}
\hline Treatments & $\begin{array}{c}\text { Grain yield } \\
\left(\mathrm{kg} \mathrm{ha}^{-1}\right)\end{array}$ \\
\hline $\mathrm{T}_{1}:$ Control & 2096 \\
\hline $\begin{array}{l}\mathrm{T}_{2}: \text { Recommended dose of } \\
\text { fertilizer }(\mathrm{RDF})\end{array}$ & 3224 \\
\hline $\begin{array}{l}\mathrm{T}_{3}: 75 \% \mathrm{RDF}+25 \% \text { vermicompost } \\
@ 5 \mathrm{t} \mathrm{ha}^{-1}\end{array}$ & 4402 \\
\hline $\mathrm{T}_{4}: 100 \%$ vermicompost @ $5 \mathrm{t} \mathrm{ha}^{-1}$ & 2996 \\
\hline $\begin{array}{l}\mathrm{T}_{5}: 75 \% \mathrm{RDF}+25 \% \text { green leaf } \\
\text { manure @ } 12.5 \mathrm{t} \mathrm{ha}^{-1}\end{array}$ & 3806 \\
\hline $\begin{array}{l}\mathrm{T}_{6}: 100 \% \text { green leaf manure } \\
\text { @ } 12.5 \mathrm{tha}^{-1}\end{array}$ & 2472 \\
\hline $\begin{array}{l}\mathrm{T}_{7}: 75 \% \mathrm{RDF}+25 \% \text { composted } \\
\text { coir pith @ } 10 \mathrm{t} \mathrm{ha}^{-1}\end{array}$ & 3513 \\
\hline $\begin{array}{l}\mathrm{T}_{8}: 100 \% \text { composted coir pith } \\
@ 10 \mathrm{t} \mathrm{ha}^{-1}\end{array}$ & 2356 \\
\hline $\begin{array}{l}\mathrm{T}_{9}: 75 \% \mathrm{RDF}+25 \% \text { sewage sludge } \\
@ 2 \mathrm{t} \mathrm{ha}{ }^{-1}\end{array}$ & 4100 \\
\hline $\mathrm{T}_{10}: 100 \%$ sewage sludge @ $2 \mathrm{t} \mathrm{ha}^{-1}$ & 2642 \\
\hline SEd & 127.02 \\
\hline $\mathrm{CD}(\mathrm{P}=0.05)$ & 266.80 \\
\hline
\end{tabular}

exchangeable calcium and magnesium content of soil might be due to release of those nutrients from added organic sources with inorganic fertilizers to the soil after mineralization released calcium and magnesium. This indicates that the addition of organic sources release exchangeable calcium and magnesium to the soil. The highest magnesium content of 0.281 percent was recorded in the treatment that received vermicompost @ $5 \mathrm{t} \mathrm{ha}^{-1}$ with 75 percent RDF and it was found to be superior to the rest of the treatments involving integrated and sole application of organic sources and it was on par with treatment received $75 \% \mathrm{RDF}$ along with sewage sludge @ 2t ha ${ }^{-1}(0.276 \%)$ and $75 \%$ RDF along with green leaf manure @ $12.5 \mathrm{t} \mathrm{ha}^{-1}$ $(0.271 \%)$ (Table.2). The lowest value was registered in the control check $(0.232 \%)$. The increase in the exchangeable calcium and magnesium contents of soil might be due to release of those nutrients from added organic sources with inorganic fertilizers to the soil after mineralization. Further, the organic acids released from the decomposition of vermicompost might have released calcium and magnesium from the exchange sites in the soil. The above observation is in close agreement with the findings of Shinde et al. (1992).

Crude protein and starch content: Application of vermicompost@5t ha ${ }^{-1}+75$ percent RDF showed superior value in crude protein content $(16.67 \%)$ and it was followed by the treatment received $75 \%$ $\mathrm{RDF}+25 \%$ Sewage sludge @ 2t ha ${ }^{-1}(15.89 \%)$ and $75 \% \mathrm{RDF}+25 \%$ Green leaf manure @ 12.5t ha ${ }^{-1}$ $(15.22 \%)$, whereas the lowest crude protein value of 6.61 percent was recorded in control. This might be ascribed to intense protein synthesis and its efficient storage in the presence of abundant supply of available nutrients. The easy availability of nutrients leading to
Table 2. Effect of organic and in organic treatments on calcium and magnesium of soil at post harvest stage.

\begin{tabular}{lcc}
\hline Treatments & Ca (\%) & Mg (\%) \\
\hline $\mathrm{T}_{1}:$ Control & 0.110 & 0.232 \\
$\mathrm{~T}_{2}:$ Recommended dose of & & \\
fertilizer (RDF) & 0.128 & 0.262 \\
$\mathrm{~T}_{3}: 75 \%$ RDF +25\% & & \\
vermicompost @ 5t ha ${ }^{-1}$ & 0.139 & 0.281 \\
$\mathrm{~T}_{4}: 100 \%$ vermicompost @ 5t & & \\
ha $^{-1}$ & 0.125 & 0.259 \\
$\mathrm{~T}_{5}: 75 \%$ RDF+ 25\% green & & \\
leaf manure @ 12.5t ha ${ }^{-1}$ & 0.131 & 0.271 \\
$\mathrm{~T}_{6}: 100 \%$ green leaf manure & & \\
@ 12.5t ha & \\
$\mathrm{T}_{7}: 75 \%$ RDF+25\% com- & 0.121 & 0.255 \\
posted coir pith @ 10t ha & \\
$\mathrm{T}_{8}: 100 \%$ composted coir pith & 0.129 & 0.268 \\
@ 10t ha & & \\
$\mathrm{T}_{9}: 75 \%$ RDF+25\% sewage & 0.120 & 0.252 \\
sludge @ 2t ha & & \\
$\mathrm{T}_{10}: 100 \%$ sewage sludge @ & 0.135 & 0.276 \\
$2 \mathrm{t}$ ha ${ }^{-1}$ & & \\
$\mathrm{SEd}$ & 0.123 & 0.257 \\
$\mathrm{CD}(\mathrm{P}=0.05)$ & 0.0011 & 0.0017 \\
\hline
\end{tabular}

balanced $\mathrm{C}: \mathrm{N}$ ratio enhancing the vegetative growth resulting in high photosynthetic activity. The crude fibre content increased the advancement of crop growth. It might be due to succulence, resulting from the cell wall thickening and reduce the uptake of $\mathrm{N}$ with advancement of crop growth reported by Roy and Singh, (2006). The crude protein content of groundnut kernel was improved significantly due to the application of biocompost as reported by Selvemurugen et al. (2013). The highest starch content of 81.34 percent was recorded in vermicompost @ 5t ha ${ }^{-1}$ combined with 75 percent RDF and it was followed by the treatment which received sewage sludge $2 \mathrm{t} \mathrm{ha}^{-1}$ with 75 percent RDF and green leaf manure @ $12.5 \mathrm{t} \mathrm{ha}^{-1}$ with the starch content of 78.44 and 76.21 percent respectively (Fig.1). It might be due to increase in the mucilage content of starch in cob over control. Increase in D-galactose, L. rhamnose and Dgalacturonic acid contents in maize crop by the application of nutrients through organic and inorganic sources which might have resulted in increase of starch content reported by Tejada and González (2009). The lowest value was recorded in the untreated control plot $(41.56 \%)$. The increasing doses of vermicompost along with inorganic fertilizers significantly increased the yield of potato tubers, starch content and dry matter content in tubers as also reported in the findings of Maria Kmetova et al. (2013).

\section{Conclusion}

The present study concluded that vermicompost along with inorganic fertilizers were efficiently used by maize crop for their growth and development and also maintainined soil fertility and increased yield of the crop. 


\section{ACKNOWLEDGEMENTS}

The authors wish to express their gratitude to the Chairman Dr. G. Jamespitchai, Tamil Nadu Agricultural University, Coimbatore and my beloved parents and my friends who supported during this experiment.

\section{REFERENCES}

Dowdy, G., Malla, R. and Totawat, K. L. (1978). Effect of municipal sewage on soil properties and chemical buildup in vegetable crop grown on Haplustepts of subhumid southern plains of Rajasthan. Journal Indian Society Soil Science, 54 (2): 226-231.

Humphries, E.C. (1956). Mineral components and ash analysis. In: Modern method of plant analysis, Vol I, (Eds. Peach, K.and Tracey, M.V.), Springer Verlag, Berlin, Germany, pp:468-502.

Jackson, M. L. (1973). Soil chemical analysis, Prentice Hall of India (pvt.) Ltd., New Delhi.

Kale, R.D. and Bano, K. (1992). Niche divergence-A limiting factor for recommendation of earthworms for biotechnology. In: Proc. Nat. Seminar on Organic Farming, MPKV, Agricultural College, Pune, pp.42-44.

Kmetova, M., Kovacik, P. and Renco, M.(2013). The effect of different doses application of dry granulated vermicompost on yield parameters of maize and potatoes. Acta fytotechnica et zootechnica, 16 (1):5-11.

Ministry of Agriculture, Government of India (2007). Water management, Crop Report -2006-2007.

Mujeeb, F., Rahmatullah, J., Akhtar and Ahmad, R. (2010). Integration of organic and inorganic $\mathrm{P}$ sources for improving $\mathrm{P}$ use efficiency in different soils. Soil and Environment, 29:122-127.

Olsen, S.R., Cole, C.V., Watanabe, F.S. and Dean, A.L. (1954). Estimation of available phosphorus in soils by extraction with sodium carbonate. Circular No.939 USDA.

Panse, V. G. and Sukhatme, P. V. (1967). Statistical methods for agricultural worker (II Edn). ICAR Pub. New Delhi, pp. 359.

Roy, D. K. and Singh, B.P. (2006). Effect of level and time on nitrogen application with without vermicompost on yield, yield attributes and quality of malt barley. Indian Journal of Agronomy,51(1):40-42.

Selvamurugan, M., Doraisamy, P. And Maheswari, M. (2013). Biomethanated distillery spentwash and pressmud biocompost aas source of plant nutrients for groundnut (Arachis hypogaea L.). Journal of Applied and Natural Science, 5(2): 328-334.

Senthil Kumar, N. and Surendran, U. (2002). Vermicomposts. Ecofriendly Evergreen revolution. Kissan World., 29(9): 49-50.

Seshaiah, M.P. (2000). Sorghum grain in poultry feed. In: Proc. Intl. Consultation, Chandrasekaran, A. R. Bundyopadhyay and H.I. Hall (Eds.). ICRISAT, Andhra Pradesh, India, 18-19 May 2000. pp. 240-241.

Shinde, P. H., Nair, R.L., Nazirker, S.K., Kandan, S.K. and Kharie, V. (1992). Evaluation of vermicompost. Proc. Natl. Sem. on Organic farming, M.P.K.V. Pune, 54-55.

Stanford, S. and English, L. (1949). Use of flame photometer in rapid soil tests of $\mathrm{K}$ and Ca. Agronomy Journal, 41: 416-447.

Subbiah, B. V. and Asija, G. L. (1956). A rapid procedure for the estimation of available nitrogen in soils. Current Science, 25: 259-260.

Tahir, M., Ayub, M., Javeed, H.M.R., Naeem, M., Rehman, H., Waseem, M. and Ali, M. (2011). Effect of different organic matter on growth ad yield of wheat (Triticum aestivum L). Pakistan Journal of life and Social Sciences, 9: 63-66.

Tejada, M. and Gonzalez, J.L. (2009). Effects of soil biological properties and rice quality and yield. Agronomy Journal, 101:336-344.

Vanlawe, B., Diets, J., Sanginga, N. and Merckx, R. (2002). Integrated plant nutrient management in Sub-Saharan Africa: From Concept to practice. Nallingford, U.K: CABI Publishing. 